\title{
A Critical Review of Solid State Sensors Used for in-situ \\ Determinations of Dissolved Elements in Molten Iron and Steel
}

Masanori IWASE

\section{1. 緒}

\section{言}

最近，溶銑・溶鋼中の成分を迅速に測定できるいわゆ る成分センサーが種々開発されている，本稿では，これ ら成分センサーの現状について概観する．また，非鉄金 属用の成分センサーについても触れる.これらの中には, 製鉄・製鋼用成分センサー開発のヒントを与えてくれる ものが多数ある.

現在までに開発された成分センサーは次の五つに分類 できる1).

( 1 ) ジルコニアを利用した副電極型ガルバニ電池セン サー

( 2 ) ジルコニア以外の新しい電解質を利用したガルバ ニ電池センサー

( 3 )製錬プロセスにおける平衡関係を利用したセン サー

（4） 3 相固体電解質を利用したガルバニ電池センサー

（5）溶融金属の物性を利用したセンサー

\section{2. 副電極型成分センサー}

\section{$2 \cdot 1$ 副電電型センサーの熱力学的基碟}

副電極型センサーは, 安定化ジルコニア $\left(\mathrm{O}^{2-}\right.$ イオ

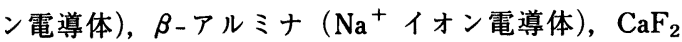
( $\mathrm{F}^{-}$イオン電導体) など, 物理的, 化学的性質が既知 でかつイオン電導度の大きい固体電解質と適当な副電極 を組み合わせて酸素以外の成分の測定を行うものであ る. この型のセンサーは, 熱力学の応用であり, 従つて 原理が明確である. 後に述べるように, 現在までのとこ ろ, 成分センサーとして今後の発展が最も期待できるの は, この副電極型および 3 相電解質型である.

副電極型センサーの原理は古くから知られており，こ の原理によつて溶融金属中の酸素以外の成分の活量を測 定した例は枚挙にいとまがないほどである.ここではこ
の原理によつて溶融 $\mathrm{Ag}$ 中の $\mathrm{Pb}$ の活量を測定した例を 取り上げて副電極型センサーの原理を説明する.

溶融 $\mathrm{Ag}$ 中の $\mathrm{Pb}$ の活量を電気化学的手法によつて測 定しようとすると, ごく単純に考えた場合には, $\mathrm{Pb}^{2+}$ イオン電導体が必要であるように思える。実際, $\left\{\mathrm{PbCl}_{2}+\mathrm{KCl}+\mathrm{LiCl}\right\}$ のような溶融塩を電解質とした 起電力法による活量測定は 1950 年代に発表されてお $\eta^{2)}$ (溶融塩電解質による活量測定自身はもつと早くか ら行われている), 電池式は

$\mathrm{Pb} /\left\{\mathrm{PbCl}_{2}+\mathrm{KCl}+\mathrm{LiCl}\right\} /\{\mathrm{Ag}+\mathrm{Pb}\}$ 電池 1

で表される.この場合, 基準極は純粋 $\mathrm{Pb}$ であり, 測定 極は $\{\mathrm{Ag}+\mathrm{Pb}\}$ 合金である.

ところが, 溶融 $\mathrm{Ag}$ 中の $\mathrm{Pb}$ の活量は, ジルコニアの ような $\mathrm{O}^{2-}$ イオン電導体を用いても測定できるのであ る. 例えばジルコニアを用いた次の電池によつて, 溶融 $\mathrm{Ag}$ 中の $\mathrm{Pb}$ の活量が測定できる3).

$$
\begin{aligned}
& \mathrm{Pt} / \mathrm{Ni}+\mathrm{NiO} / \mathrm{ZrO}_{2}(\mathrm{CaO}) /\{\mathrm{Ag}+\mathrm{Pb}\} \\
& +\mathrm{PbO} / \mathrm{Ir}
\end{aligned}
$$

ここで, 基準極は〈 $\mathrm{Ni}+\mathrm{NiO}\rangle$ 混合物であり, 基準極 には， $\mathrm{Pb}$ を全く含まないことに注意していただきたい. 一方，測定極には， $\{\mathrm{Ag}+\mathrm{Pb}\}$ 合金だけでなく, $\mathrm{PbO}$ を共存させてある.この $\mathrm{PbO}$ が副電極である.この副 電極が存在するので, 測定対象である $\{\mathrm{Ag}+\mathrm{Pb}\}$ 合金 と副電極間で次式の反応が平衡に到達する.

$\mathrm{Pb}$ (in $\mathrm{Ag})+(1 / 2) \mathrm{O}_{2}=\mathrm{PbO}$

( 1 )式の平衡定数は,

$$
K(1)=a_{\mathrm{PbO}} / P_{\mathrm{O} 2} a_{\mathrm{Pb}}
$$

で与えられ, 温度のみの関数であるから, $\mathrm{PbO}$ の活量 が既知の場合には，ジルコニア.固体電解質によつて( 1 ) 式の平衡酸素分圧を測定すれば, $\mathrm{Ag}$ 中の $\mathrm{Pb}$ の活量が 測定できる.

以上の説明からわかるとおり，この原理によつて $\mathrm{Pb}$ 昭和 63 年 4 月 20 日受付 (Received Apr. 20,1988)（依頼解説）

* 京都大学工学部助教授 工博 (Faculty of Engineering, Kyoto University, Yoshidahonmachi Sakyo-ku Kyoto 606) Key words : solid state galvanic sensors : auxiliary electrode : hot metal : iron and steelmaking : tri-phasic electrolyte. 
の活量を測定するためには, 副電極中の $\mathrm{PbO}$ の活量は 一定でなければならない，上の例では純粋 $\mathrm{PbO}$ を用い ることによつて $\alpha_{\mathrm{PbO}}=1$ としている.

次に $\mathrm{PbO}$ と他の酸化物 $\mathrm{M}_{x} \mathrm{O}_{y}$ との複合酸化物 $\mathrm{PbO} \cdot \mathrm{M}_{x} \mathrm{O}_{y}$ を副電極として使用する場合に必要な条件 を考えてみる。まず第 1 は，二つの相を共存させなけれ ばならないことである. 例えば $\mathrm{PbO} \cdot \mathrm{ZrO}_{2}$ を副電極と して使用したとする.この場合, 副電極系の熱力学自由 度は 2 である.つまり温度を決めただけでは副電極中の $\mathrm{PbO}$ の活量は規定できない。この場合には, 温度と組 成が規定されて始めて, $\mathrm{PbO}$ の活量が規定される。こ の場合の組成とは $\mathrm{PbO} \cdot \mathrm{ZrO}_{2}$ 中の組成であり, $\mathrm{PbO}$ と $\mathrm{ZrO}_{2}$ のモル比と考えてよい.

$\mathrm{PbO} \cdot \mathrm{ZrO}_{2}$ 中の $\mathrm{PbO} / \mathrm{ZrO}_{2}$ モル比は 1 に非常に近い が,このモル比がごくわずかに変化しただけでも， $\mathrm{PbO}$ の活量は大きく変化する。このように $\mathrm{PbO}$ の活量が大 きく変化すると, ( 2 )式からわかるように, 酸素分圧が 同じでも $\mathrm{Pb}$ の活量は大きく異なる.つまり, $\mathrm{PbO}$. $\mathrm{ZrO}_{2} 1$ 相では副電極として作動しないのである.この 場合には $\left\langle\mathrm{PbO} \cdot \mathrm{ZrO}_{2}+\mathrm{ZrO}_{2}\right\rangle 2$ 相共存とすることが 必要である.

第 2 の条件は他の酸化物 $\mathrm{M}_{x} \mathrm{O}_{y}$ が溶融金属中で十分熱 力学的に安定であることが必要である.もし, 副電極中 の $\mathrm{M}_{x} \mathrm{O}_{y}$ が不安定であれば, (1)式の平衡反応と同時に

$\mathrm{M}_{x} \mathrm{O}_{y}$ (in aux. electrode) $=x \mathrm{M}+(y / 2) \mathrm{O}_{2} \cdots \cdots(3)$ の反応が進行し，これによつて界面の酸素分圧が変化す るので起電力は $\mathrm{Pb}$ の活量に対応しなくなる.

製鉄・製鋼用の副電極型の成分センサーとは，以上の 説明に用いた $\mathrm{Ag}$ を $\mathrm{Fe}$ に置き換え, $\mathrm{Pb}$ を測定目的と する溶銑・溶鎆中の成分に置き換えたものである.

\section{$2 \cdot 2$ 製鉄·製鋼用副電極型成分センサー}

副電極型センサーの開発は 1980 年代の始め頃から行 われており4) 6)，主としてガス用サルファーセンサーな どに利用されている.

製鉄・製鋼用の副電極型としては溶鋼用アルミセン サー, 溶鋼用クロムセンサー, 溶銑用シリコンセンサー

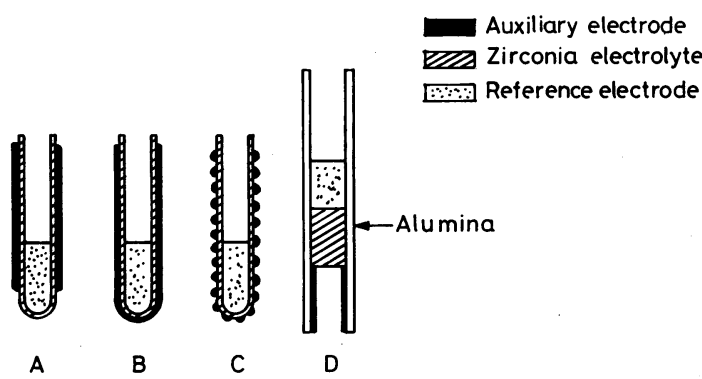

Fig. 1. Schematic illustrations of electrochemical sensors incorporating auxiliary electrodes.
などが開発されている7)〜11). 現在までに開発された製 鉄・製鋼用副電極型センサーの構造を模式的に示すと Fig. 1のようになる. どの夕イプのものも，(1)副電極, (2)ジルコア固体電解質, (3)標準極から構成されている. 以下に, 個々の副電極型センサーを概観し，先に述べた 熱力学的原理がどのように生かされているかを解説す る.

$2 \cdot 2 \cdot 1 \quad \mathrm{Al}_{2} \mathrm{O}_{3}$ 副電極型溶鋼用アルミセンサー

$\mathrm{Al}_{2} \mathrm{O}_{3}{ }^{\dagger}$ を副電極とした溶鋼用アルミセンサーが種々 報告されている778).

アルミセンサーは, ジルコニア管の表面に $\mathrm{Al}_{2} \mathrm{O}_{3}$ を コーティングして副電極としたもので, 電池式は

$$
\begin{gathered}
\mathrm{Cr}+\mathrm{Cr}_{2} \mathrm{O}_{3} / / \mathrm{ZrO}_{2}(\mathrm{MgO}) / / \mathrm{Al}_{2} \mathrm{O}_{3} \\
\mathrm{Fe}
\end{gathered}
$$

と書ける.このアルミセンサーの構造は, 酸素センサー とほとんど同じであり，一端閉管状のジルコニアの表面 に $\mathrm{Al}_{2} \mathrm{O}_{3}$ をコーティングしてある点が異なるだけであ る.アルミセンサーであるからと言つて, $\mathrm{Al}$ の化学ポ テンシャルが既知の基準電極を使用するわけではない.

実際，文献 7），8）の例では，酸素センサーに使用され ている〈Cr$\left.+\mathrm{Cr}_{2} \mathrm{O}_{3}\right\rangle$ 基準極を使用している.このセ ンサーの副電極は, ジルコニアの表面全体にわたつて コーティングされているのではなく, ジルコニアの閉端 部にコーティングのない部分を設けて, 溶鋼/副電極/ジ ルコニアから成る 3 相界面を確保している（Fig. $1 \mathrm{~A}$ 参照).

このアルミセンサーをアルミキルド鋼中へ浸漬すると

$2 \mathrm{Al}($ in $\mathrm{Fe})+3 \mathrm{O}($ in $\mathrm{Fe})=\mathrm{Al}_{2} \mathrm{O}_{3}$

の反応が, 溶鋼/ジルコニア/副電極から成る 3 相界面で

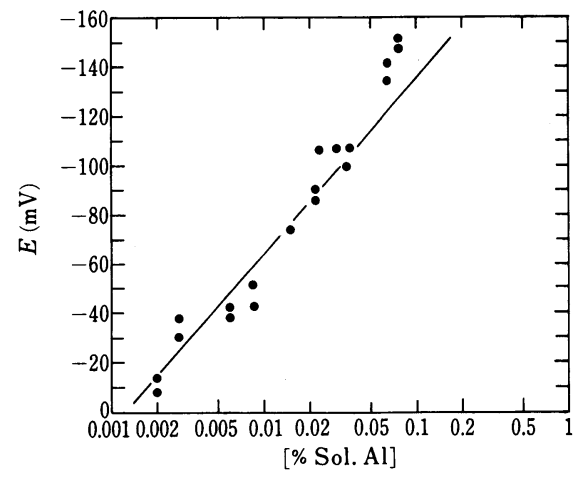

Fig. 2. Relation between measured cell potentials of electrochemical aluminium sensor of the type $\mathrm{Cr}$ $+\mathrm{Cr}_{2} \mathrm{O}_{3} / \mathrm{ZrO}_{2}(\mathrm{MgO}) / \mathrm{Fe} \mathrm{Al}_{2} \mathrm{O}_{3}$ as the function of the concentration of aluminium, which is soluble in acid.

† $\left\langle\mathrm{Al}_{2} \mathrm{O}_{3}+\mathrm{MgF}_{2}\right\rangle$ 混合物，あるいは $\left\langle\mathrm{Al}_{2} \mathrm{O}_{3}+\mathrm{AlF}_{3}\right\rangle$ 混合物を副電極 としたものもある. $\mathrm{Al}_{2} \mathrm{O}_{3}-\mathrm{MgF}_{2}$ 系, $\mathrm{Al}_{2} \mathrm{O}_{3}-\mathrm{AlF}_{3}$ 系ともに, Miscibility gap が大きいと推定され, $\mathrm{Al}_{2} \mathrm{O}_{3}$ の副電極中の $\mathrm{Al}_{2} \mathrm{O}_{3}$ の活量 は1であると考えられる。 
平衡に達し，酸素ポテンシャルを測定すれば，溶鋼中の [Al] がわかる. Fig. 2 には, このセンサーの起電力と 酸可溶 $\mathrm{Al}$ 濃度, [\% Sol. $\mathrm{Al}]$, との関係を示した.

$\mathrm{Al}_{2} \mathrm{O}_{3}$ コーティングを副電極として作動させるために は, ジルコニアの表面のコーティング相の一部を剝がし， 副電極/溶鎆/電解質から成る 3 相界面を形成することが 決定的に有効であるが, コーティング方法, あるいはコー ティング厚み, さらにはコーティング層の気孔率によつ ては, ジルコニア管の表面全体に $\mathrm{Al}_{2} \mathrm{O}_{3}$ をコーティン グしても溶鋼/副電極/ジルコニア 3 相界面を確保できる 場合がある. 通常, $\mathrm{Al}_{2} \mathrm{O}_{3}$ をジルコニア表面にコーティ ングするには, $\mathrm{Al}_{2} \mathrm{O}_{3}$ の微粉末を水および有機系バイン ダーと混合してスラリー状とし，この中へジルコニアを 浸漬し, 自然乾燥して作成することが多い.こういうコー ティング層を持つたジルコニアを溶鋼中へ浸漬すると， 水分あるいは有機成分の急激な蒸発により, コーティン グ層の一部にき裂あるいは剩離を生じる，剥離を生じた 場合は無論のこと, き裂を生じた場合にも，き裂部を通 して溶鋼がコーティング層へ侵入し，ジルコニアと接触 する，逆に言うと，現状のコーティング技術では，溶䤡 中へ浸漬した時, ジルコニアと溶龬との接触を完全に断 ち切るようなコーティングは不可能である. また, コー ティング層の厚みが通常は $0.05 \mathrm{~mm}$ 程度と非常に薄い ものであることにも注目する必要がある。つまりこのよ うにコーティング層が非常に薄いので，ごくわずかなき 裂あるいは，剝離部を通して溶鋼が簡単にジルコニア表 面へ到達しうる.

また先に述べたように一部の $\mathrm{Al}_{2} \mathrm{O}_{3}$ 副電極には $\mathrm{MgF}_{2}$ が混合されているので, 溶鋼温度へ急熱すると, $\mathrm{MgF}_{2}$ の融解に伴つて見かけの体積が大幅に減少し, 溶 鋼/副電極/ジルコニア 3 相界面を形成しやすくなる.

以上の説明からわかるように，ジルコニアの全表面を $\mathrm{Al}_{2} \mathrm{O}_{3}$ でコーティングしたとしても, 溶鋼/ジルコニア $/ \mathrm{Al}_{2} \mathrm{O}_{3}$ コーティング (副電極) から成る 3 相界面が確 保され, 結果的には $\mathrm{Al}_{2} \mathrm{O}_{3}$ コーティングをジルコニア 表面の一部にのみ実施した場合と同じ現象が起こる.

ジルコニアの全表面に $\mathrm{Al}_{2} \mathrm{O}_{3}$ をコーティングした副 電極型アルミセンサーは, ジルコニア固体電解質と $\mathrm{Al}_{2} \mathrm{O}_{3}$ 固体電解質を重ねた, いわゆる “Bielectrolyte cell”+2であると考えがちであるが, Fig. 1 A に示すよ うに, $\mathrm{Al}_{2} \mathrm{O}_{3}$ コーティング層の一部が剩がされているの で,(あるいは $\mathrm{Al}_{2} \mathrm{O}_{3}$ コーティングが溶鎆中へ浸漬と同 時に剥離するので), $\mathrm{Al}_{2} \mathrm{O}_{3}$ は電解質としての役目は果 たしていない. また仮に $\mathrm{Al}_{2} \mathrm{O}_{3}$ コーティングがジルコ

†2 $\mathrm{ZrO}_{2}(\mathrm{CaO})$ 電解質の表面に $\mathrm{ThO}_{2}\left(\mathrm{Y}_{2} \mathrm{O}_{3}\right)$ 電解質を比較的厚めに コーティンクし，かつ $\mathrm{ThO}_{2}\left(\mathrm{Y}_{2} \mathrm{O}_{3}\right)$ のコーティング層にき裂や剝離 を生じないよう, 徐熱して溶鋼中へ浸漬し, 極低浱度域における溶 鋼中酸素㰾度を測定する方法が 1976 年に報告されている ${ }^{13)}$.この場 合には, $\mathrm{ZrO}_{2}(\mathrm{CaO})$ と $\mathrm{ThO}_{2}\left(\mathrm{Y}_{2} \mathrm{O}_{3}\right)$ の両方が電解質として作動し うるので "Bielectrolyte cell" (Doppelelektrolyzelle) と呼ばれるこ とがある.
ニアの全表面を覆つていたとしても， $\mathrm{Al}_{2} \mathrm{O}_{3}$ は， SCHMALZRIED $^{14)}$ によれば $1300^{\circ} \mathrm{C}$ 以上では電子電導体で あるとされているので, Bielectrolyte cell の可能性は 非常に低い.

コーティング相（つまり副電極）が $\mathrm{Al}_{2} \mathrm{O}_{3}$ であるか ら $\mathrm{Si}$ キルド鋼中へ浸漬してもシリコンセンサーとして は使用できない.また，酸素ポテンシャルが高い場合に は, ジルコニア/溶鉄界面の酸素ポテンシャルは, (4) 式ではなく, 溶鉄中の溶解酸素自身によつて決定される から，このアルミセンサーを転炉終点のように酸素濃度 の高い溶鋼中へ浸漬した場合には, アルミセンサーでは なく酸素センサーとして作動する.

$2 \cdot 2 \cdot 2\left[\mathrm{ZrO}_{2}+\mathrm{ZrO}_{2} \cdot \mathrm{SiO}_{2}\right]$ 副電極型溶銑用シリコ ンセンサー

$\left.\mathrm{ZrO}_{2}+\mathrm{ZrO}_{2} \cdot \mathrm{SiO}_{2}\right] 2$ 相共存を副電極に用いた溶鉄 用シリコンセンサーが IWASE により報告されている9).

このセンサーの電池式は

$$
\mathrm{Mo}+\mathrm{MoO}_{2} / / \mathrm{ZrO}_{2}(\mathrm{MgO}) / / \underset{\text { 溶銑 }}{\mathrm{ZrO}_{2}}+\mathrm{ZrO}_{2} \cdot \mathrm{SiO}_{2}
$$

電池 4

であるまた副電極反応は

$\mathrm{ZrO}_{2}+\mathrm{Si}+\mathrm{O}_{2}=\mathrm{ZrO}_{2} \cdot \mathrm{SiO}_{2}$

と書ける.このセンサーの構造は, Fig. $1 \mathrm{C}$ に示すよ うに, ジルコニア管の表面に $\left\langle\mathrm{ZrO}_{2}+\mathrm{ZrO}_{2} \cdot \mathrm{SiO}_{2}\right\rangle 2$ 相混合物を副電極として, 班点状に塗り付けたものにな つている.このように班点状に塗り付けることによつて, 溶鉄/副電極/ジルコニアから成る 3 相面を確保してい る.

また，副電極が $\left\langle\mathrm{ZrO}_{2}+\mathrm{ZrO}_{2} \cdot \mathrm{SiO}_{2}\right\rangle$ の 2 相共存に なつていることに注意しなければならない. 副電極を

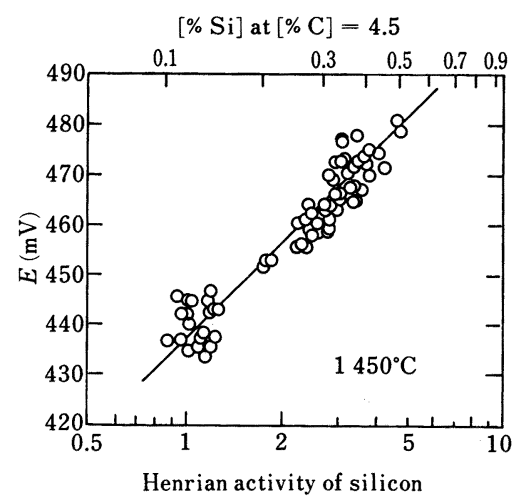

Fig. 3. Measured cell potentials of electrochemical silicon sensor incorporating $<\mathrm{ZrO}_{2}+\mathrm{ZrO}_{2}$. $\mathrm{SiO}_{2}>$ mixture as auxiliary electrode plotted against silicon concentration in molten $\mathrm{Fe}+\mathrm{Si}+$ C) alloys at $1450^{\circ} \mathrm{C}$. 
$\mathrm{ZrO}_{2} \cdot \mathrm{SiO}_{2} 1$ 相とした場合には, $\mathrm{SiO}_{2}$ の活量は一定 にならない (これは, 先の $\mathrm{PbO} \cdot \mathrm{ZrO}_{2}$ の場合と同じで ある).

$\left\langle\mathrm{ZrO}_{2}+\mathrm{ZrO}_{2} \cdot \mathrm{SiO}_{2}\right\rangle$ 副電極は, 溶銑温度付近でも 固体であるので，ジルコニアの表面に塗布したのち $1400^{\circ} \mathrm{C}$ 付近で焼成している. また副電極とジルコニア 間の密着は非常に強固であり，溶銑中へ浸漬後ただちに 取り出して水中急冷してもジルコニアから剝がれること はない.

このセンサーの実験室における使用結果を Fig. 3 に 示す.

シリコンセンサーで測定できるのは $[\% \mathrm{Si}]$ ではなく， $\mathrm{Si}$ の活量である. したがつて, $\mathrm{Si}$ の活量から $[\% \mathrm{Si}]$ を求めるには, $\mathrm{Si}$ の活量にもつとも大きく影響する [\%C] を知る必要があるが, 通常の高炉操業では, 出鉄 中に $[\% \mathrm{C}]$ はそれほど大きく変化しない，高炉鋳床に おける測定結果を Fig. 4 に示す.

$2 \cdot 2 \cdot 3 \mathrm{CaF}_{2}+\mathrm{SiO}_{2}$ 副電極型溶銑用シリコンセン サー

この型のセンサーの電池式は

$\mathrm{Cr}+\mathrm{Cr}_{2} \mathrm{O}_{3} / / \mathrm{ZrO}_{2}(\mathrm{MgO}) / / \mathrm{CaF}_{2}+\mathrm{SiO}_{2} \ldots$ 鉄

と書ける. 副電極は, $\left\{\mathrm{CaF}_{2}+\mathrm{SiO}_{2}\right\}$ 混合物であり, これを水および有機バインダーと混合してスラリー状と し,この中へジルコニアを浸漬することにより,コーティ ングしてある。この副電極は溶鉄温度に達すると $\mathrm{SiO}_{2}$ 飽和の $\left\{\mathrm{SiO}_{2}-\mathrm{CaF}_{2}\right\}$ 液体スラグを生成すると考えられ る. 副電極反応は,

$\mathrm{Si}$ (溶鉄) $+2 \mathrm{O}=\mathrm{SiO}_{2}\left(\right.$ in $\mathrm{CaF}_{2}-\mathrm{SiO}_{2}$ slag $) \cdots(6)$ である.ただし使用温度と $\mathrm{CaF}_{2} / \mathrm{SiO}_{2}$ 比によつては， $\mathrm{SiO}_{2}$ 飽和ではなく均一液相を生じ, 副電極中の $\mathrm{SiO}_{2}$ の活量が一定にならない可能性がある.

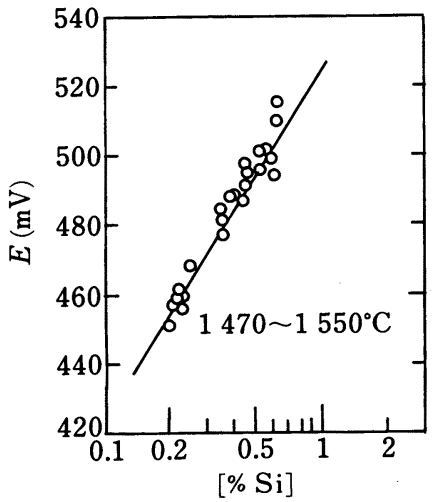

Fig. 4. Results of in-plant test of the electrochemical silicon sensor incorporating $<\mathrm{ZrO}_{2}+$ $\mathrm{ZrO}_{2} \cdot \mathrm{SiO}_{2}>$ mixture as auxiliary electrode.
このシリコンセンサーは, ジルコニアの全表面に副電 極をコーティングしてあるが, 測定温度では, 個相 + 液相\}の 2 相共存になるので，溶銑中へ浸漬と同時に副 電極の一部が剝離し，ジルコニアと溶鉄の直接接触が起 こり, 結果的には溶鉄/ジルコニア/副電極から成る 3 相 界面が形成されるものと考えられる.

\section{$2 \cdot 3$ クロムセンサー}

HEINTZ and JANKE ${ }^{10)}$ は, Fig. 1 D に示す構造の副電極 型クロムセンサーを報告している.ここでは, ペレット 状のジルコニア固体電解質をアルミナ管の内側に装着 し，このアルミナ管に $\mathrm{Cr}_{2} \mathrm{O}_{3}$ を塗り付けて副電極とし ている. 電池式は

$$
\begin{array}{r}
\mathrm{Cr}+\mathrm{Cr}_{2} \mathrm{O}_{3} / / \mathrm{ZrO}_{2}(\mathrm{MgO}) / / \mathrm{Cr}_{2} \mathrm{O}_{3} \\
\mathrm{Fe}+\mathrm{Cr}+\mathrm{C}
\end{array}
$$

である.このクロムセンサーの特徴は, アルミナ管の内 側に固体電解質を設置していることである.これは, 副 電極/溶鋼/ジルコニア 3 相界面の局部平衡が溶鋼の流動 によつて乱されないように配虑したものと考えられる.

最近, 学振 19 委員会製銚センサー小委員会成分セン サーグループによつて副電極型クロムセンサーが開発さ れている ${ }^{11)}$. 詳細は学振製鋼第 19 委員会製鋼センサー 小委員会最終報告書（昭和 64 年 5 月刊行予定）を参照 されたい.

これらのクロムセンサーの副電極反応は,

$2 \mathrm{Cr}$ (in $\mathrm{Fe})+3 \mathrm{O}=\mathrm{Cr}_{2} \mathrm{O}_{3}$

である. 副電極中の $\mathrm{Cr}_{2} \mathrm{O}_{3}$ の活量が既知となるよう, 純粋 $\mathrm{Cr}_{2} \mathrm{O}_{3}$ あるいは $\mathrm{Cr}_{2} \mathrm{O}_{3}$ (s) 飽和の $\{\mathrm{CaO}-$ $\left.\mathrm{SiO}_{2}-\mathrm{Cr}_{2} \mathrm{O}_{3}\right\}$ 融体を副電極とするなど, 種々の工夫が なされている. 副電極のジルコニア表面へのコーティン グは, プラズマ溶射，あるいは，スラリーへの浸漬によ つて行われており, ジルコニア管の全表面をコーティン

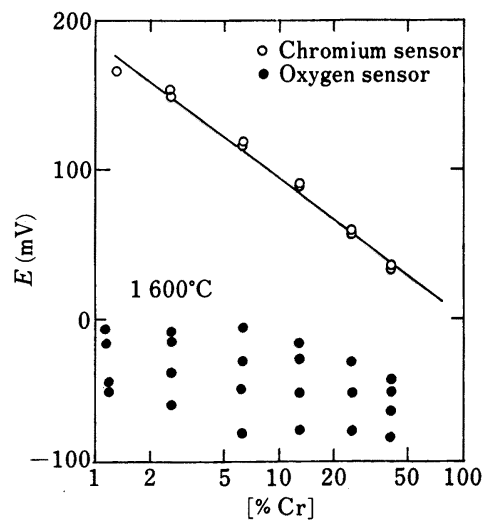

Fig. 5. Measured cell potentials of electrochemical chromium sensor incorporating auxiliary electrode plotted against chromium concentration in molten $\{\mathrm{Fe}+\mathrm{Cr}+\mathrm{C}\}$ alloys at $1600^{\circ} \mathrm{C}$. 


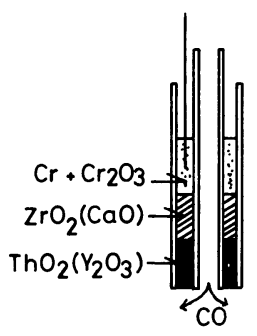

Fig. 6. Schematic illustration of solid state carbon sensor incorporating gaseous carbon monoxide as auxiliary electrode after ROMERo et $a^{15)}$.

グしてある，ただし，溶融 $\{\mathrm{Fe}+\mathrm{Cr}+\mathrm{C}\}$ 合金中へ浸 漬すると，ほとんどの場合，コーティング層が一部剝離 し, $\mathrm{Fe}-\mathrm{Cr}-\mathrm{C}$ 合金/ジルコニア/副電極から成る 3 相界 面が確保されているようである。 なお実験結果の一例を Fig. 5 に示す.

$2 \cdot 4$ カーボンセンサー

RoMERo et al. ${ }^{15)}$ は Fig. 6 に示す構造の副電極型カー ボンセンサーを発表している.この場合, 副電極は 1 atm の CO ガスであり, 副電極反応は

$$
\mathrm{C}+\mathrm{O}=\mathrm{CO}(\mathrm{g})
$$

である. 電池式は

$$
\begin{aligned}
\mathrm{Cr}+\mathrm{Cr}_{2} \mathrm{O}_{3} / / \mathrm{ZrO}_{2}(\mathrm{MgO}) & \\
& / / \mathrm{ThO}_{2}\left(\mathrm{Y}_{2} \mathrm{O}_{3}\right) / \mathrm{CO} \\
& \mathrm{Fe}+\mathrm{C}
\end{aligned}
$$

と書ける.ここでは $\mathrm{ZrO}_{2}(\mathrm{MgO})$ と $\mathrm{ThO}_{2}\left(\mathrm{Y}_{2} \mathrm{O}_{3}\right)$ の両 方が電解質として作用しており, いわゆる Bielectrolyte cell になつている.

\section{3. 新しい電解質を利用した成分センサー}

最近 10 年間に, 水溶液並みの高い電導度を持つた 種々の固体電解質（超イオン電導体と呼ばれることがあ る）が開発されている. しかしながら，これら新固体電 解質のほとんどは比較的低温でのみ安定な化合物が多 く，製鉄・製鋼温度でも使用できる固体電解質は，現在 までのところ, ジルコニア, トリア，ベータアルミナ以 外には見つかつていない. また将来的にも発見される可 能性は非常に少ない.したがつて, 新電解質を利用して 成分センサーを開発しようとする試みは，かなり行われ てはいるものの, 液体電解質を用いたもの以外は，製鉄 ・製鋼用に使用できる可能性は非常に少ない.ここでは, 個々の新電解質の問題点も同時に述べる.

$3 \cdot 1$ マンガンシリケート型マンガンセンサー

$\mathrm{MnO}^{-\mathrm{SiO}_{2}}$ 系固体電解質を用いたマンガンセンサー が 1975 年に発表されている ${ }^{16)}$. 固体電解質は $7.4 \mathrm{wt} \%$ $\mathrm{MnO}$ を含むマンガンシリケートであるが，1\%の Na が 不純物として含有されている. 電池式で書けば,

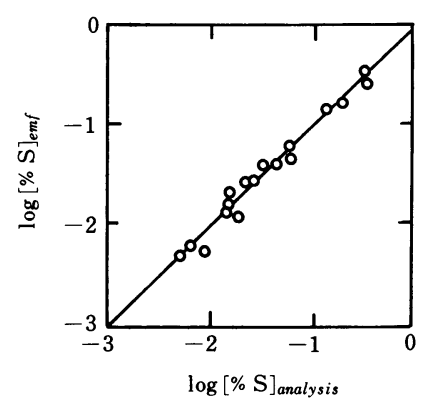

Fig. 7. Relation between sulfur concentrations measured by electrochemical sulfur sensor incorporating $\mathrm{CaS}\left(+\mathrm{TiS}_{2}\right)$ and those by chemical analysis after Egami et $a^{17)}$.

$\mathrm{Mn} / / \mathrm{MnO}-\mathrm{SiO}_{2} / / \mathrm{Fe}-\mathrm{Mn}$ 電池 8

である. $\mathrm{MnO}-\mathrm{SiO}_{2}$ 系固体電解質の電導機構はよくわ かつていない. $\mathrm{Mn}^{2+}$ イオン電導体であるとされている が, 遷移金属のイオン電導体は非常に考えにくいので, むしろ, 不純物として含まれている $\mathrm{Na}^{+}$イオンの電導 体であると考えた方がよい. 文献 16）の実験結果を見 ると, 起電力と鉄中の $\mathrm{Mn}$ 濃度の関係は, 理論式とは 一致しないが, 起電力と $[\% \mathrm{Mn}]$ の対応は满足すべき ものが得られている. センサーとしての実用化を考える 場合には必ずしも理論值と一致する必要はないが, 固体 電解質中の $\mathrm{MnO}$ の熱力学的安定性に問題があるので, 溶銑・溶鋼中での利用は困難と考えられる.実際, 実用 化は進んでいない.

\section{$3 \cdot 2 \mathrm{CaS}$ 電解質型サルファーセンサー}

$\mathrm{CaS}$ あるいは $\mathrm{CaS}$ 系固溶体を用いた溶銑用サル ファーセンサーが EGAMI et al. ${ }^{17)}$ によつて報告されてい る. 電池式は,

$$
\mathrm{Mo} / \mathrm{W}+\mathrm{WS}_{2} / / \mathrm{CaS}\left(+\mathrm{TiS}_{2}\right) / / \mathrm{Fe}-\mathrm{C}-\mathrm{S} / \mathrm{Mo}
$$

電池 9

と書ける. 固体電解質の $\left\{\mathrm{CaS}^{-} \mathrm{TiS}_{2}\right\}$ 系固溶体は $\mathrm{S}^{2-}$ イオン電導体であると考えられており，Fig. 7 に示す ように Ar 雾井気下の測定では, センサーの起電力から 求めた溶鉄中の $[\% \mathrm{~S}]$ と分析值の間には満足すべき一 致が得られている．たたし大気下における実操業では $\mathrm{CaS}$ の酸化反応をいかに防止するかが問題になる.

同様に溶銅用サルファーセンサーが ONo et al. ${ }^{18)}$, FISCHER and $\mathrm{J}_{\mathrm{ANKE}}{ }^{19)}$ によつて報告されている. 電池式 はそれぞれ

$\mathrm{Mo}+\mathrm{Mo}_{2} \mathrm{~S}_{3} / / \mathrm{CaS}\left(+\mathrm{ZrS}_{2}\right) / / \mathrm{Cu}-\mathrm{S}$ (l) alloy .................................電池 10

$\mathrm{Cu}-2 \mathrm{wt} \% \mathrm{~S}$ alloy//CaS//Cu-S (l) alloy …...電池11 である. FISCHER and JANKE の例では理論値と実測值は 一致しているとは言い難い.

以上のように硫化物電解質を用いたサルファーセン 
サーが種々開発されてはいるが, ほとんどは実用化され ていない。この原因の一つに, 硫化物系の固体電解質は イオン電導度が低く, センサーの内部抵抗が非常に大き くなり, 応答速度が遅くなることが挙げられる. CaS に異原子価の硫化物を固溶させると, $\mathrm{S}^{2-}$ イオン空孔 濃度が上昇して $\mathrm{S}^{2-}$ イオン電導度が上がると期待しが ちであるが, 硫化物系固体電解質にはその可能性はほと んどない20).

また電解質の $\mathrm{CaS}$ が溶鉄・溶鋼中では熱力学的に不 安定であることも問題である. 詳細に計算しなくとも, 製鉄・製鋼プロセスにおける以下の経験を思い出せば上 の意味がわかる．「 CaS がもし溶鉄・溶鋼中で熱力学的 に安定であるなら，脱硫用スラグを用いずとも脱硫がで きるはずである， $\mathrm{CaS}$ は実際には安定でないので，溶 銑・溶鋼を脱硫するためには $\mathrm{CaS}$ の活量を下げる必要 があり，そのため脱硫用スラグを使用している.」

\section{$3 \cdot 3$ 液体電解質型溶銑用シリコンセンサー}

$\mathrm{CaO}-\mathrm{MgO}-\mathrm{SiO}_{2}-\mathrm{CaF}_{2}-\mathrm{Al}_{2} \mathrm{O}_{3}$ 系液体スラグを電解質 に用いた溶銑用シリコンセンサーが江上, 尾上ら ${ }^{21)} に$ よつて報告されている. 電池式は

$\mathrm{Mo} / \mathrm{Si} / / \mathrm{CaO}-\mathrm{MgO}-\mathrm{SiO}_{2}-\mathrm{CaF}_{2}-\mathrm{Al}_{2} \mathrm{O}_{3} / /$ 溶鉄/ $\mathrm{Mo}$ 電池12

である. $\mathrm{CaO}-\mathrm{MgO}-\mathrm{SiO}_{2}-\mathrm{CaF}_{2}-\mathrm{Al}_{2} \mathrm{O}_{3}$ 系の液体スラグ を電解質に用いている.このスラグの電導機構は不明な 点が多いが $\mathrm{Si}^{4+}$ イオン電導体とは考えられない。また 最近同じ型のセンサーがイタリアで使用されており ${ }^{22)}$, 溶鉄中の [Si] の連続測定が可能であると報告されてい るが詳細は不明である.これらの例では, 測定は再現性 よく行われているようである. 同様の液体電解質型シリ

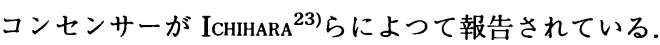

液体電解質の最大の問題は, 拡散電位をいかに制御す るかにある。これを $\left\{\mathrm{CaO}-\mathrm{SiO}_{2}-\mathrm{Al}_{2} \mathrm{O}_{3}\right\}$ 系液体電解質 を例にとつて説明する.

いま $\left\{\mathrm{CaO}-\mathrm{SiO}_{2}-\mathrm{Al}_{2} \mathrm{O}_{3}\right\}$ 系均一液体を電解質として 下記の電池を組んだとする.

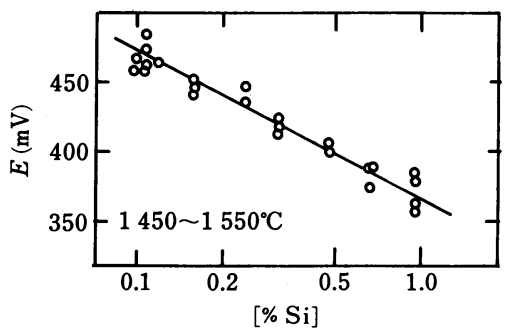

Fig. 8. Measured cell potentials of electrochemical silicon sensor incorporating liquid silicate electrolyte as the function of silicon concentration in molten $\{\mathrm{Fe}+\mathrm{Si}+\mathrm{C}\}$ alloys at $1600^{\circ} \mathrm{C}$ after NARITA et $a l^{21)}$.
$\mathrm{Si} / /\left\{\mathrm{CaO}-\mathrm{SiO}_{2}-\mathrm{Al}_{2} \mathrm{O}_{3}\right\} / / \mathrm{Fe}+\mathrm{Si}+\mathrm{C}$ 電池13

基準極の純粋 $\mathrm{Si}$ と $\left\{\mathrm{CaO}-\mathrm{SiO}_{2}-\mathrm{Al}_{2} \mathrm{O}_{3}\right\}$ の電解質との 界面（電池 13 の左極）における平衡は

$\mathrm{Si}$ (pure) $+\mathrm{O}_{2}=\mathrm{SiO}_{2}$ (in $\mathrm{CaO}_{2}$ in $\mathrm{CaO}$ $\mathrm{SiO}_{2}-\mathrm{Al}_{2} \mathrm{O}_{3}$, left)

と表せる．一方，測定極の $\{\mathrm{Fe}+\mathrm{Si}+\mathrm{C}\}$ 合金と電解 質との界面（電池 13 の右極）における平衡は

$\mathrm{Si}$ (in $\mathrm{Fe}$ ) $+\mathrm{O}_{2}=\mathrm{SiO}_{2}$ (in $\mathrm{CaO}-\mathrm{SiO}_{2}-\mathrm{Al}_{2} \mathrm{O}_{3}$, right)

と書ける.

いま $\left\{\mathrm{CaO}-\mathrm{SiO}_{2}-\mathrm{Al}_{2} \mathrm{O}_{3}\right\}$ 系液体電解中の $\mathrm{SiO}_{2}$ の活 量が電池 13 の左極と右極で等しい場合には, (9), (10) 式の電解質の両端における Si の化学ポテンシャルの差 が酸素ポテンシャル差に対応し, 結果的には酸素濃淡電 池となる.この場合の電池の起電力は, 電解質が $\mathrm{O}^{2-}$ イオン電導体であつてもあるいは, $\mathrm{Si}^{4+}$ イオン電導体 であつても，とにかくイオンの輸率が 1 でありさえすれ ば, いわゆる NERNST の式で与えられる.つまり, 電解 質中の $\mathrm{SiO}_{2}$ の活量が一定であれば, 電池 13 の起電力 はシリコンの活量に対応する. しかしながら,これはあ くまで, 電解質中の $\mathrm{SiO}_{2}$ の活量が一定の場合である.

$\left\{\mathrm{CaO}-\mathrm{SiO}_{2}-\mathrm{Al}_{2} \mathrm{O}_{3}\right\}$ 系均一液体を電解質として使用 した場合には，基準極/液体電解質界面（左極）と，測 定極/電解質界面（右極）とでは, $\mathrm{SiO}_{2}$ の活量が異なる と考えざるを得ない. 均一な液相中で活量に不均一が生 じれば, 当然, 濃度差も存在する.ここで問題は，この 濃度差をもたらす物質が，「イオン，すなわち電荷を持 つた粒子である」という点にある. 電荷を持つた粒子に 濃度勾配が生じれば, その濃度勾配によつて荷電粒子が 移動しており（つまり拡散が生じており), 荷電粒子の 移動は何らかの電位勾配を引き起こすと考えざるを得な い.この電位勾配が拡散電位である.

このような拡散電位のものでは, 起電力はシリコンの ポテンシャル差に対応しない.この拡散電位の大きさを 見積もろうという試みは多くの研究者によつてなされて きたが，水溶液電解質以外では成功していない。 したが つて, 液体電解質を利用する場合には, 電解質中の成分 の活量を一定にすることが必要である.

$\left\{\mathrm{CaO}-\mathrm{SiO}_{2}-\mathrm{Al}_{2} \mathrm{O}_{3}\right\}$ 系の場合には, 3 元系であるから， 3 相を共存させなければならない.この意味から, 現在 までに報告されている液体電解質型シリコンセンサー は, 多少なりとも拡散電位の影響を受けていると考えら れる. ただし成分センサーは, 実験室的な熱力学測定と は異なり, 七ンサーの起電力と成分濃度との間に何らか の対応がありさえすれば実用に耐える場合が少なくな い.こういう観点から, 現在までに報告されている液体 電解質型シリコンセンサーの実験結果を見る限りは, 十 分実用に耐えるようである. しかしながら，今後の成分 センサーの開発には, 上記に述べた熱力学的あるいは電 
気化学的考察を十分行うことが必要である.

\section{$3 \cdot 4$ 溶融アルミニウム用水素センサー}

1978 年に GEE and F RAY $^{24)}$ は溶融アルミニウム用水素 センサーを開発している. 電解質は $\mathrm{CaH}_{2}$ である. 電池 式は

$\mathrm{Ca}+\mathrm{CaH}_{2} / / \mathrm{CaH}_{2} / / \mathrm{Al}-\mathrm{H}$ alloy/ 電池14

である. しかしながら $\mathrm{CaH}_{2}$ 電解質の熱力学的安定性か ら考えてこのセンサーが溶鉄・溶鋼用水素センサーとし て使用できる可能性はほとんどない。

\section{$3 \cdot 5$ 溶融錫用ナトリウムセンサー}

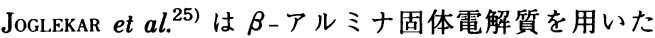
ナトリウムセンサーを開発している。電池式は

$\mathrm{Fe} / \mathrm{Na}(1) / \beta-\mathrm{Al}_{2} \mathrm{O}_{3} / \mathrm{Na}-\mathrm{Sn}(1)$ 電池15 である.この電池により, 約 $500^{\circ} \mathrm{C}$ の溶融 $\mathrm{Sn}$ 中の $\mathrm{Na}$ の測定に成功している. $\beta-\mathrm{Al}_{2} \mathrm{O}_{3}$ は $\mathrm{Na}^{+}$イオン電導体 であるが，電導度が非常に大きく，七ンサー用電解質と しては最適である.しかしながら吸湿性が強く，取扱い が不便という欠点をもつている。この電解質は，溶銑溶 鋼用センサーよりも，むしろガスセンサー用電解質とし て期待できる.

$3 \cdot 6$ 溶鋼用窒素センサー

AIN を固体電解質に用いた窒素センサーが報告され ている ${ }^{26)}$. しかしながら，溶鋼中における AlN の熱力 学的安定性はかなり疑問であるから，実用化は困難と考 えられる。

\section{4. 製鍊プロセスにおける平衡関係を 利用したセンサー}

製錬プロセスによつては，ある成分の濃度を求めるの に酸素ポテンシャルを測定すれば実質上その成分の濃度 がわかるという場合がある。これはその製錬プロセスに 特有の平衡関係を利用したものである.このような場合, 厳密には成分センサーと呼べないかも知れないが，ここ ではあえて成分センサーに分類する。

\section{$4 \cdot 1$ 溶銅用垔鉛センサー}

$\mathrm{Cu}-\mathrm{Zn}$ 合金を溶製する際，銅中の亜鉛濃度をコント ロールする必要がある. WILDER et al. ${ }^{27)}$ は $\mathrm{Cu}$ と Zn で は酸素に対する親和力が大きく異なることから， $\{\mathrm{Cu}-\mathrm{Zn}\}$ 合金を溶解すると実操業であるかを問わず, 固体の $\mathrm{ZnO}$ で飽和しているに違いないと考え, $\mathrm{Cu}-\mathrm{Zn}$ 合金中の酸素ポテンシャルは

$$
\mathrm{ZnO}(\mathrm{s})=\mathrm{Zn} \text { (in } \mathrm{Cu})+\mathrm{O} \text { (in } \mathrm{Cu})
$$

で決まると考えた。 そこで次式で

$\mathrm{Pt} / \mathrm{Ni}+\mathrm{NiO} / / \mathrm{ZrO}_{2}(\mathrm{CaO}) / / \mathrm{Cu}-\mathrm{Zn} / \mathrm{Ta} \cdots \cdots$. 電池 16 表される溶銅用酸素センサーを $\{\mathrm{Cu}-\mathrm{Zn}\}$ 合金中へ浸漬 して, 起電力と溶銅中の $\mathrm{Zn}$ 濃度の関係を調査したとこ ろ, Fig. 9 に示すように, $995^{\circ} \mathrm{C}$ では起電力と亜鉛濃 度の間に極めて良好な相関関係が成立することを見いだ した. 結果的には, 電池 16 は酸素センサーでありなが

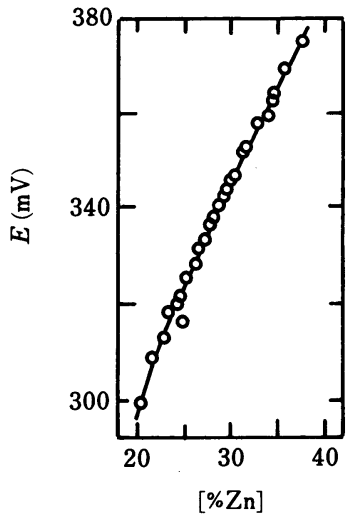

Fig. 9. Measured cell potentials of electrochemical oxygen sensor as the function of zinc concentration in molten $\{\mathrm{Cu}+\mathrm{Zn}\}$ alloys at $995^{\circ} \mathrm{C}$ after WILDER et $a l^{27)}$.

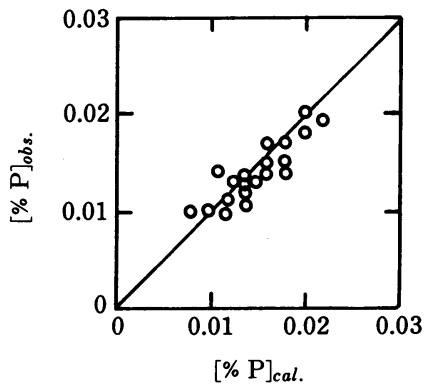

Fig. 10. Relation between phosphorus concentrations estimated by electrochemical oxygen sensor and those by chemical analysis after KawAI and $\mathrm{UsuI}^{28)}$

ら Zn センサーとして作動していることになる.

この例は今後の成分センサーの開発を考える上で，極 めて示唆に富んでいる．もし Zn センサーを開発しよj として $\mathrm{Zn}^{2+}$ イオン電導体を探すことから研究をス タートしていたのでは, 研究は失敗に終わつていただろ う。なぜなら $\mathrm{Zn}^{2+}$ イオン電導体は現在に至るもいま だ発見されていないからである. 熱力学的に考えて, $\mathrm{Cu}-\mathrm{Zn}$ 合金はどんな条件で溶解しても，必ず $\mathrm{ZnO}$ で飽 和しているに違いないと考えたことが $\mathrm{Zn}$ センサーの開 発につながつている.ここでもセンサー開発の鍵は熱力 学であることがわかる.

\section{$4 \cdot 2$ 製鋼用 $\mathrm{P}$ センサー}

溶銅用 Zn センサーよりももつと巧妙に酸素センサー を使用して，結果的にはPセンサーとして応用している 例が $\mathrm{NKK}^{28)}$ から発表されている. Fig. 10 に通常の酸 素センサーで求めた起電力值を元に計算した上下吹き転 
炉吹鍊末期の溶鋼中 $[\% \mathrm{P}]_{c a l}$. と分析值 $[\% \mathrm{P}]_{o b s}$. の関係 を示す．ただし，この相関関係がどの製鉄所の転炉でも 成立するという保証はどこにもない.Fig. 10 のような 相関が得られた背景には以下のような条件が満たされる ように転炉操業を行つていることが挙げられる.

（1）メタルースラグ間の平衡が達成されやすい条件 を作つている.

（2）炬内の物質収支がかなり正確に把握されてい る.

\section{3 相電解質型センサー}

3 相電解質（Tri-phasic electrolyte）は, 副電極を使 用せず, 電解質中の成分の活量を完全な熱力学的平衡下 におき，これによつて溶鋼中の成分を測定するものであ る.この型のセンサーは副電極型以上に熱力学の知識を 必要とするもので, 特に 3 元系の Compatibility triangle に関する十分な考察が必要である.

IwASE $^{29)}$ は $\mathrm{ZrO}_{2}-\mathrm{MgO}-\mathrm{SiO}_{2}$ 系の状態図をもとに 3 相 電解質を設計し, 溶銑用 $\mathrm{Si}$ センサーに応用している.

Fig. 11 に 3 元系の状態図を示す. 図中の黒丸で示した 組成の $\mathrm{ZrO}_{2}-\mathrm{MgO}-\mathrm{SiO}_{2}$ 系電解質は, $\left\{\right.$ Cubic $\mathrm{ZrO}_{2}$ (固 溶体 $)+$ monoclinic $\mathrm{ZrO}_{2}$ (固溶体) $\left.+2 \mathrm{MgO} \cdot \mathrm{SiO}_{2}\right\}$ の 3 相共存になつていることがわかる. したがつて，この 3 相電解質中のそれぞれの成分, $\mathrm{MgO}, \mathrm{ZrO}_{2}, \mathrm{SiO}_{2}$, の活 量は, 温度が決まれば一義的に決まる，またこういう焼 結体の組織は, 粒界に析出した $2 \mathrm{MgO} \cdot \mathrm{SiO}_{2}$ と, 半安

$1723 \mathrm{~K}$

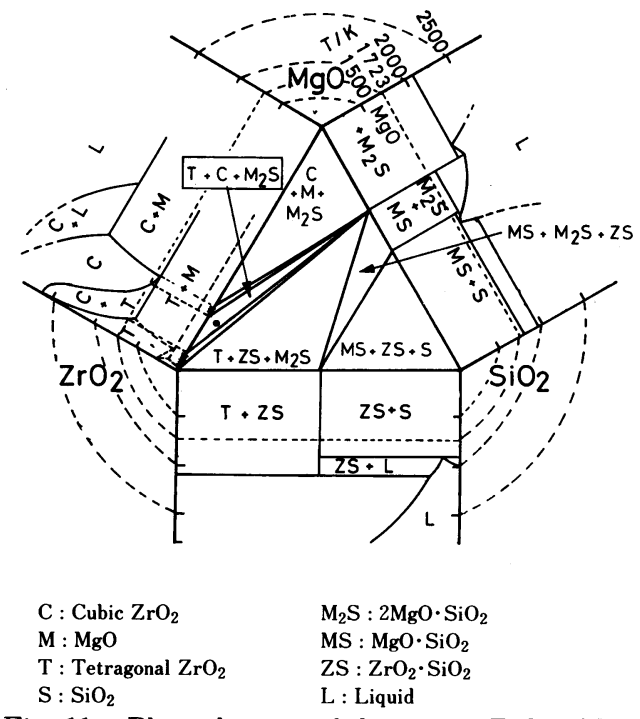

Fig. 11. Phase diagram of the system $\mathrm{ZrO}_{2}+\mathrm{MgO}$ $+\mathrm{SiO}_{2}$. Solid circle indicates the bulk composition of tri-phasic zirconia electrolyte after IWASE et $a l^{29)}$.
定化 $\mathrm{ZrO}_{2}-\mathrm{MgO}$ 系固体電解質（つまり $\{$ Cubic + Monoclinic\} の 2 相共存) とから成つている. そこでこ の 3 相電解質を用いて次の電池を組む.

$\mathrm{Mo}+\mathrm{MoO}_{2} /$ Tri-phasic electrolyte

$/ \mathrm{Fe}+\mathrm{C}+\mathrm{Si}$ 電池17

溶銑/ 3 相電解質界面の平衡は

$$
\begin{aligned}
2 \mathrm{MgO} & +\mathrm{Si}(\text { in } \mathrm{Fe})+20(\text { in } \mathrm{Fe}) \\
& =2 \mathrm{MgO} \cdot \mathrm{SiO}_{2} \ldots \ldots \ldots \ldots \ldots
\end{aligned}
$$

である。あるいは

$$
\mathrm{Si}(\text { in } \mathrm{Fe})+2 \mathrm{O}(\text { in } \mathrm{Fe})=\mathrm{SiO}_{2}\left(\text { in } 2 \mathrm{MgO} \cdot \mathrm{SiO}_{2}\right)
$$

と書くこともできる. いずれにせよ, 電解質中の $\mathrm{MgO}$ と $\mathrm{SiO}_{2}$ の活量は電解質が 3 相共存であることによつて 固定されているので, 酸素ポテンシャルの測定から $\mathrm{Si}$ の化学ポテンシャルがわかることに変わりはない. 酸素 ポテンシャルは 3 相電解質の Matrix である $\mathrm{ZrO}_{2}-\mathrm{MgO}$ 系固体電解質によつて測定される.

Fig. 12 には, 3 相電解質型溶鉄用 $\mathrm{Si}$ センサーの起 電力と $\{\mathrm{Fe}+\mathrm{C}+\mathrm{Si}\}$ 合金中の $\mathrm{Si}$ の活量の関係を示 した. 3 相電解質型 Si センサーは, 電解質の製作が副 電極型よりもはるかに容易で低コストである.

\section{6. 成分に敏感な物性を利用した成分センサー}

\section{$6 \cdot 1$ 溶鋼用 $\mathrm{C}$ センサー}

$\mathrm{Fe}-\mathrm{C}$ 系合金の融点が [\%C] によつて変化することを 利用してCセンサーが開発されており, 転炉サブランス

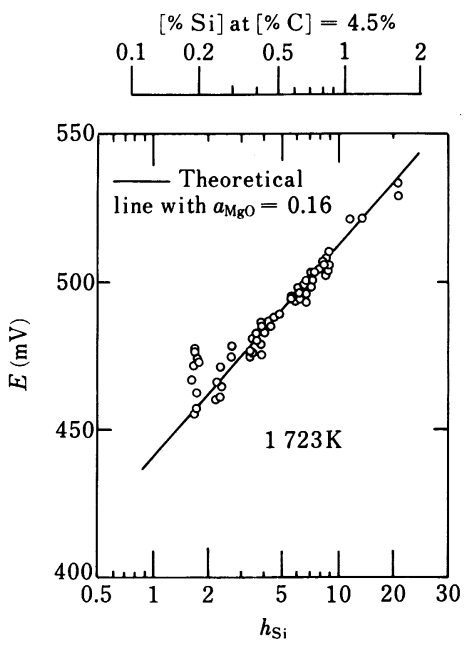

Fig. 12. Measured cell potentials of electrochemical silicon sensor incorporating tri-phasic zirconia electrolyte as the function of silicon concentration in molten $\{\mathrm{Fe}+\mathrm{Si}+\mathrm{C}\}$ alloys at $1450^{\circ} \mathrm{C}$ after IWASE et $a^{29)}$. 


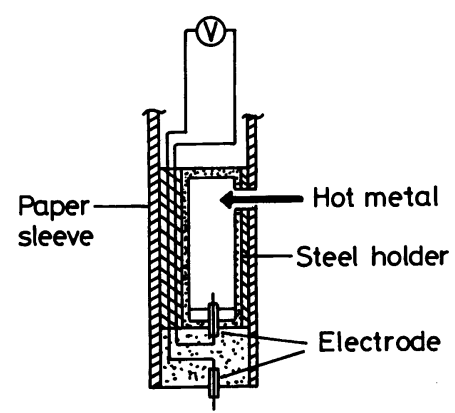

Fig. 13. A schematic illustration of silicon sensor based on thermoemf measurements after MaтsuокA et $a l^{30)}$.

用に市販されている．ただし極低C域での測定精度は低 w.

$6 \cdot 2$ 溶銑用 $\mathrm{Si}$ センサーおよび溶銅用 $\mathrm{Al}$ センサー

鉄系合金のジーベック係数が [\%Si] に対して敏感に 変化することを利用した Si センサーが開発されてい $ろ^{30)}$. Fig. 13 にこのセンサーの構造を示す. センサー を溶鉄中へ浸漬すると, センサー内へサンプルが吸引さ れ，約 $100^{\circ} \mathrm{C}$ の温度勾配下におかれる。この時に発生 する熱起電力を測定して $[\% \mathrm{Si}]$ を求める.

尾上ら ${ }^{31)}$ は同じ原理によつて溶鋼中の酸可溶アルミ ニウム迅速測定用センサーを発表している.

\section{7. 製銑·製鋼プロセスにおいて使用できる 新固体電解質の可能性}

以上に紹介した例からわかるように，成功例のほとん どは, 何らかの意味でジルコニアを利用したものである. これに対し，たとえば溶鋼中の $\mathrm{P}$ 直接測定できる $\mathrm{P}^{3-}$ イオン電導体が, 将来発見されるかどうかを考え てみよう。もし $\mathrm{P}^{3-}$ イオン電導体があるとすれば, そ れは一般式では $\mathrm{M}_{m} \mathrm{P}_{n}$ と書けるであろう．ここで $\mathrm{M}$ は 金属元素である.こういう化合物が将来発見されたとし て，それが果たして溶鉄・溶鋼中で熱力学的に安定であ るかどうかは非常に疑問である.もし $\mathrm{M}_{m} \mathrm{P}_{n}$ が製鋼の 温度, 酸素ポテンシャル下で安定であるなら, 金属元素 Mを溶鋼中へ添加した時,

$$
m \mathrm{M}+n \mathrm{P}(\text { in } \mathrm{Fe})=\mathrm{M}_{m} \mathrm{P}_{n} \cdot
$$

の反応が起こり，いわゆる還元脱りんができることにな る.しかしながら， $\mathrm{Ca}-\mathrm{CaF}_{2}$ 系フラックスによつて還 元脱りんを行うためには，どれほど低い酸素ポテンシャ ルが要求されるかを思い起こすと, $\mathrm{M}_{m} \mathrm{P}_{n}$ が通常の製鋼 温度·製鋼酸素ポテンシャル下で安定である可能性は非 常に低いことがわかる.

\section{8. おわりに}

溶銑・溶鋼の成分を瞬時に知ることができる成分セン サーは，製銑・製鋼技術者の長年の夢であつたが，最近 のこの分野の進歩を見ると必ずしも「夢」とは言えない 状況に来ているように思われる. 特に， 3 相電解質は 4 元系（Tetra-phasic electrolyte）さらには多元系 (Multi-phasic electrtolye) へと進んでいくとその可能 性は無限にある。

また以上に述べたセンサーのほとんどは熱力学の応用 であり, 特に, 状態図と相律についての考察がセンサー 開発には不可欠である. 本稿では失敗例もかなり取り上 げたが,これは失敗例の方がむしろ今後の成分センサー 開発の参考になると考えたからである.

本稿で紹介した 3 相電解質型溶銑用シリコンセンサー の開発には, (社) 日本鉄鋼協会の昭和 62 年度研究テー マ公募にもとづく特定基礎研究会単独依頼研究による研 究費の交付を受けたものである．また本稿の執筆にあた つては坂尾 弘名古屋大学名誉教授および雀部 実千葉 工業大学教授から有益なコメントをいただいた。また学 振 19 委員会製鋼センサー小委員会委員各位には未発表 のデータを御提供いただいた。記して謝意を表します。

\section{文献}

1 ) 岩瀬正則: 学振製鋼第 19 委員会提出資料（昭和 63 年 5 月）または M. IWASE: Advances in Ceramic Science, 24 (1989), 印刷中

2 ) V. N. EREMENKo: Ukrain. Khim. Zhur, 23 (1953), p. 6

3 ) M. IWASE, K. FuJimura and T. MoRI: Trans. Jpn. Inst. Met., 19 (1978), p. 377

4 ) $K . T$. JaCoB, M. IWASE and Y. WASEDA: J. Appl. Electrochem., 12 (1982), P. 57

5 ) $K$. T. JACOB, M. IWASE and Y. WASEDA: Solid State Ionics, 23 (1987), p. 245

6 ) K. T. JACOB, M. IWASE and Y. WaSEDA: Advanced Ceramic Material, 1 (1986), p. 264

7 ) M. Mugita and Y. MiYaShita: Nippon Kokan Technical Report Overseas, 33 (1981), p. 47

8 ) $K$. Murase, $K$. Takeuchi and $K$. Yamada: Chemical Sensors, ed. by S. SEIYAMA et al. (1983), p. 296 [Kodan-Sha]

9 ) M. IwaSE: Scandinavian Journal of Metallurgy, 19 (1988), p. 50

10) M. HeinTZ and D. JANKE: Proceedings of W. O. Philbrook Memorial Symposium (1988 年 4 月) [Iron and steel Society of A. I. M. E.

11）岩瀬正則, 尾上俊雄: 学振第 19 委製鋼センサー小委員会 提出資料 (昭和 62 年 5 月)

12) K. S. Goto and W. Pluschekell: Physics of Electrolyte, ed. by J. HLadick, Vol. II (1972), p. 540 (Academic Press, London]

13) D. JANKE and W. A. Fischer: Arch. Eisenhüttenwes., 47 (1976), p. 147

14) H. SchmalzRIED: Z. Phys. Chem. (Frankfurt), 38 (1963), p. 87

15) A. R. Romero, J. HaRKKI and D. JANKE: Steel Research, 57 (1986), p. 485

16) E. L. ECKFELDT and R.M. TAYLOR: Metal-Slag-Gas 
Reactions and Processes, ed. by $Z$. A. Foroulis and $W$. W. Smeltzer (1975), p. 875 [Electrochemical Society Inc., Princeton, New Jersey]

17) A. Egami, $T$. Onouye and $K$. Narita: Solid State Ionics, 3 \& 4 (1981), p. 617

18) K. Ono, T. OISH and J. Moriyama: Solid State Ionics, 3 \& 4 (1981), p. 555

19) W. $A$. FISCHER and D. JANKE: Metallurgische Elektrochemie (1975), p. 426 [Verlag Stahleisen mbH.]

20) C. N. R. RaO and K. P. Pisharady: Prog. Solid State Chem., 10 (1976), p. 207

21）成田貴一, 尾上俊雄, 江上 明, 西 誠治: 学振 19 委員 会提出資料 (昭和 59 年 2 月)

22) $K$. ICHIHARA, D. JANKE and H.-J. ENGELL: Steel Research, 57 (1986), p. 166

23) M. Palchettic, $M$. Ginli, $M$. Pallela, $G$. Federico,
O. Simonelli and G. Vecchiola: Iron Steelmaker, 15 (1988) 1, p. 31

24) $R$. GEE and D. J. FraY: Met all. Trans., 9 (1978), p. 427

25) B. V. Joglekar, $P$. S. Nicholson and $W$. W. SMELTZER: Can. Met. Quart., 12 (1973), p. 155

26) W. A. FisCHER and $C$. SCHUH: Arch. Eisenhüttenwes., 46 (1975), p. 101

27) T. C. WILDER and W. F. GALIN: Trans. Met all. Soc. AIME, 245 (1969), p. 1287

28）河井良彦, 碓水 務: 学振 19 委員会製鋼反応協議会基調 講演提出資料 (昭和 63 年 5 月)

29) M. IWASE: Steel Res., 59 (1988) 10, p. 433

30) $M$. Matsuoka, $K$. Urata, $R$. Fujiwara, $M$. Tominaga and T. OGURA: Trans. Iron Steel Inst. Jpn., 27 (1987), p. 814

31）尾上俊雄: 学振 19 委員会製鋼センサー小委員会提出資料 (昭和 62 年 2 月) 